\title{
The Competencies and Challenges of Leading a Student Entrepreneurship Organisation in South Africa
}

\author{
Olawale Fatoki \\ Department of Business Management, Turfloop Campus, University of Limpopo, \\ Limpopo Province, South Africa \\ E-mail: Olawale.fatoki@ul.ac.za
}

\section{Doi:10.5901/mjss.2014.v5n10p216}

\begin{abstract}
The study investigates the competencies that are needed to successfully lead a student entrepreneurship organisation. In addition, the study seeks to identify the challenges that student entrepreneurship organisations leaders face in achieving goals. Data was collected through the use of self-administered questionnaire in a survey. The survey was conducted at one of the universities in the Limpopo province of South Africa. The participants in the study were the nine student leaders of Enactus in the university. Nine questionnaires were distributed and seven were returned. Descriptive statistics was used for data analysis. The results indicate that communication, team work, time management and honesty and integrity are the most important competencies and traits that are needed to successfully lead a student entrepreneurship organisation. The results also indicate that a major challenge to achieving goals is the lack of commitment by members.
\end{abstract}

Keywords: competencies, challenges, leadership, student entrepreneurship organisation, South Africa.

\section{Introduction}

According to Beeka and Rimmington (2011) and Buang (2011), entrepreneurship is one of the career options for youths and graduates. Sardeshmukh and Smith-Nelson (2011) point out that there is the need to provide the kind of education that is needed to develop an opportunity-oriented entrepreneurial mind set among tertiary students. In addition, employers want graduates that are entrepreneurially minded. Lourenco et al. (2013) point out that the development of an entrepreneurial mind-set and/or enterprising skills is on the agenda for developing graduates in order to enhance their employability. Employers are looking for graduates equipped with skills that will enable them to act in enterprising ways so they can deal effectively with a difficult business environment, and a personal life that is increasingly full of uncertainties and complexities. Thus, focusing on entrepreneurship is one of numerous solutions to reduce youth and graduate unemployment in South Africa.

Arham et al. (2013) point out that effective leaders are needed to manage organisations as they contribute towards the success or failure of an organisation. According to Tarabishy et al. (2005) and Yang (2008), organisations must cultivate a new form of entrepreneurial leader that can maximize their companies' capabilities. The entrepreneurial leader lends his or her vision, leadership style, and strategy to the very essence or core of the business. This is one of the major variables influencing the outcome and success of the business. The leader of an organisation must have certain competencies that can ensure organisation success. Stoof (2005) defines competency as the combination of knowledge, skills and attitudes that are required to perform a task. A considerable amount of literature suggests that competencies are necessary for the development and survival of businesses and organisations (Phelan and Sharpley, 2007). An organisation that was with the aim of promoting entrepreneurship in the universities is Enactus (Formerly known as Students in Free Enterprise (SIFE)). According to Zeng et al. (2011) and Enactus (2014), Enactus is a global nonprofitable organization working in partnership with business and higher education. Enactus establishes student teams on university campuses that are empowered to teach ethical entrepreneurship in their local communities. The Enactus team has become an alternative business model for student entrepreneurship education. Bagheri and Pihie (2011) note that many uncertainties, complexities, and challenges are associated with successfully leading entrepreneurial activities. In addition, leaders require specific capabilities in order to achieve organisation vision. There is a scarcity of empirical literature on leadership competencies among university students as potential leaders either in their own businesses or previously established organisations. 


\section{Objectives of the Study}

The objectives of the study are: (1) to investigate the competencies needed to successfully lead a student entrepreneurship organisation and (2) to identify the challenges that student entrepreneurship organisations leaders face in achieving goals.

\section{Literature Review}

Gupta et al. (2004) point out that leadership essentially involves a relationship of mutual commitment between a leader and a group of followers in pursuit of a collective goal. Winston and Patterson (2006) note that a "leader is one or more people who selects, equips, trains, and influences one or more follower(s) who have diverse gifts, abilities, and skills and focuses the follower(s) to the organization's mission and objectives causing the follower(s) to willingly and enthusiastically expend spiritual, emotional, and physical energy in a concerted coordinated effort to achieve organizational mission and objectives". Slavkin (2010) points out that there is no single precise definition of the term leadership. However, leadership can be described as the act of making a difference. Leadership entails sustaining, improving, or changing strategic directions within an organisation. Leadership is about motivating and coordinating human and financial resources to achieve a common goal. Prewitt et al. (2011) agree that there are many definitions of leadership and that the differences in the definitions are not just a case of scholarly nitpicking. They reflect deep disagreement about identification of leaders and leadership processes. The authors define leadership as the ability to influence others by setting and inspiring example. Leadership involves creating a vision of the organizational future, devising a strategy for achieving that vision, and communicating that vision to all members of the organization. DiMattia (2013) points out that leadership refers to someone who guides or influences others.

The leader of an organisation must have certain competencies that can ensure organisation success. Gruban (2003) defines competencies as the "ability to use knowledge and other capabilities, necessary for successful and efficient accomplishment of an appointed task, transaction of work, goal realization, or performance of a certain role in the business process. Competencies encompass knowledge, expertise, skills, personal and behavioural characteristics, beliefs, motives, values". Svetlik, (2005) describes competence as the ability of an individual to activate, use and connect the acquired knowledge in the complex, diverse and unpredictable situations. According to Hellriegel et al.(2008), competencies are sets of knowledge, skills, behaviours and attitudes that contribute to personal effectiveness Penchev and Salopaju (2011) point out that competencies are the sum of experiences and the knowledge, skills, values and attitudes acquired during lifetime, which are necessary for effective performance in a job or life role. Certain competencies are needed by the leaders of an organisation. Thach \& Thompson (2007), point out that leadership competencies include vision and goal-setting, interpersonal skills, self-knowledge and technical competence. Other competencies include integrity/honesty, communication, diversity consciousness, problem-solving, decision team leadership, conflict management and social and environmental responsibility,

Entrepreneurial competencies are needed to lead an entrepreneurial organisation. Inyang and Enuoh (2009) define entrepreneurial competencies as those clusters of related knowledge, attitudes, and skills which an entrepreneur must acquire through managerial training and development to enable him produce outstanding performance, and maximize profit, while managing a business venture or an enterprise. Entrepreneurial competencies are characteristics such as generic and special knowledge, motives, traits, self-images, social roles and skills which result in birth of venture, its survival and/or growth. According to Kiggundy (2002), entrepreneurial competencies refer to the sum of the entrepreneur's requisite attributes for successful and sustainable entrepreneurship. These attributes include attitudes, values, beliefs, knowledge, skills, abilities, personality, wisdom, expertise (social, technical, and managerial), mind-set, and behavioural tendencies. Studies such as Onstenk (2003), Inyang and Enuoh (2009) and Phelan and Sharpley (2012) find that entrepreneurial competencies are necessary for the development and survival of an organisation.

The Human Capital theory by Schultz (1961) points out that knowledge, skills and competencies are a form of capital. Schultz compares the acquisition of knowledge and skills to acquiring the means of production. The difference in earnings between people relates to the differences in access to education and health. Becker (1964) in his seminar book entitled "Human Capital" views human skills and competencies as similar to physical means of production such as factories and machines.

According to Baum et al. (2001), entrepreneurial competencies include knowledge, cognitive ability, selfmanagement, administration, human resources, decision skill, leadership, opportunity recognition, opportunity development and organisation skill. Man et al. (2002) identify six major competency areas which are (1) opportunity, (2) organizing, (3) strategic, (4) relationship, (5) commitment, and (6) conceptual competencies. Dixon et al. (2005) classify 
entrepreneurial competencies into eight clusters. The clusters are team leadership, communication, trustworthiness, organisational skills, basic business skills, problem solving skills, personal traits and creativity. Inyang and Enuoh (2009) point out that entrepreneurial competencies include time management, marketing management, business ethics, leadership,, decision-making, and financial management. Similarly, Mitchelmore and Rowley (2013) identify four clusters of entrepreneurial competencies. These are personal and relationship, business management, entrepreneurial and human resources competencies. Bagheri and Pihie (2011) point out that there are two specific types of competencies for the leaders of entrepreneurial venturing. These are personal competencies and functional competencies. Personal competencies include proactiveness, innovativeness, and risk taking. Functional competencies allow a leader to mobilize a group of people, communicate the entrepreneurial vision with them, and enhance their self-efficacy and commitment to achieve the entrepreneurial vision.

\section{Research Methodology}

The survey was conducted at one of the universities in the Limpopo province of South Africa. The participants in the study were the nine student leaders of Enactus in the university. Enactus is an international non-profit organization that brings together student, academic and business leaders who are committed to using the power of entrepreneurial action to improve the quality of life and standard of living for people in need (Enactus, 2014). Because of the small population, the whole population was used as the sample size. Self-administered questionnaire was used for data collection. The questionnaire was divided into three parts. (1) Biographical information (2) the importance of certain competencies to effective job performance. The questions on competencies were developed through a thorough review of the literature on leadership and entrepreneurial competencies and (3) the challenges in achieving goals. The questionnaire included both close ended and open-ended questions. To measure competencies, the five point Likert scale question type ranging from "1: not all all important, 2: slightly important, 3: moderately important, 4: very important and 5 extremely important was used. For the challenges, open ended questions were used. Descriptive statistics was used for data analysis.

\section{Results and Discussions}

\subsection{Response rate and biographical information}

Nine questionnaires were distributed to the leadership of Enactus and seven questionnaires were returned. The response rate was $77.8 \%$. Four males and three females participated in the study. Three of the participants were from the Department of Business Management, three from Development Planning and Management and one from Information Studies. Four participants were at undergraduate level and three participants at postgraduate level.

\subsection{Competencies}

Participants in the survey were asked to rate the importance of the following competencies to the effective performance of their job as leaders of a university students' entrepreneurship organisation

Table 1: the importance of competencies

\begin{tabular}{|l|c|c|}
\hline Competencies & Mean & Standard deviation \\
\hline Basic competencies & & \\
\hline Oral communication (speaking) & 4.750 & 0.827 \\
\hline Reading & 4.714 & 0.591 \\
\hline Listening & 4.714 & 0.694 \\
\hline Writing & 3.857 & 0.628 \\
\hline Numeracy and quantitative literacy & 4.000 & 0.622 \\
\hline Computer literacy & 3.857 & 0.714 \\
\hline Administrative competencies & & \\
\hline Supervisory & 4.429 & 0.591 \\
\hline Budgeting & 4.286 & 0.777 \\
\hline People competencies & & \\
\hline Autonomous (individual) decision-making skill & 4.000 & 0.915 \\
\hline Ability to work with different people (group work) & 5.000 & 1.010 \\
\hline
\end{tabular}




\begin{tabular}{|l|c|c|}
\hline People management (ability to manage different people) & 4.857 & 1.085 \\
\hline Conflict management & 4.714 & 0.885 \\
\hline Ability to dissemination information to students and other constituents & 4.143 & 0.824 \\
\hline Ability to establishing networks and partnerships with necessary constituents & 4.571 & 0.805 \\
\hline Entrepreneurial orientation competencies & & \\
\hline Creativity and innovation & 4.571 & 0.927 \\
\hline Risk-taking & 4.429 & 0.850 \\
\hline Proactiveness & 4.429 & 0.726 \\
\hline Project management & 4.286 & 0.629 \\
\hline Conceptual competencies & & \\
\hline Problem solving & 4.429 & 0.627 \\
\hline Planning and organising & 4.571 & 0.926 \\
\hline Decision making & 4.571 & 0.901 \\
\hline Personal competencies and traits & & \\
\hline Dependability & 3.143 & 0.673 \\
\hline Responsibility & 4.143 & 0.729 \\
\hline Understanding of ethics & 4.714 & 0.614 \\
\hline Ability to withstand work pressure & 4.429 & 0.621 \\
\hline Emotional control & 4.286 & 0.599 \\
\hline Positive attitude towards work & 4.429 & 0.674 \\
\hline Time management & 4.857 & 0.939 \\
\hline Self-confidence, positive image & 4.714 & 0.795 \\
\hline Adaptability, flexibility & 4.714 & 0.727 \\
\hline Enthusiasm & 4.571 & 0.724 \\
\hline Self-discipline & 4.714 & 0.931 \\
\hline Honesty, integrity & 5.000 & 1.001 \\
\hline Broad understanding of diversity & 4.429 & 0.623 \\
\hline Social responsibility & 4.714 & 0.696 \\
\hline
\end{tabular}

Table 1 depicts the importance attached to certain competencies by the leadership of a student entrepreneurship organisation. Under basic competencies, the results indicate that oral communication (speaking), listening, writing, reading, numeracy and quantitative literacy as well as computer literacy are basic competencies that are needed to successfully lead a student entrepreneurship organisation. Oral communication (speaking) with a mean of 4.750 seems to be the most important basic competency. Payne (2005) and Vathanophas and (2007) find that communication competence is needed for effective job performance. Pagon et al. (2008) point out that communication competency is one of the leadership competencies that an individual needs for every day problem solving and to perform a concrete activity. Moghimi (2013) note that communication competency is needed to perform management functions such as planning, organising, leading and controlling. Without communication competency, it is impossible for a leader to perform these functions.

Under people competencies, team (group) competency has a mean of 5.00 indicating the importance attached to this competency. Baker et al. (2006) and Olupeliyawa et al. (2009) find that teamwork is an essential component of achieving highly effective organizations. A team performs interdependent tasks in order to achieve common goals.

Under entrepreneurial orientation competencies, creativity and innovation has the highest importance attached with a mean of 4.571. Kettunen (2011) points out that the process of managing knowledge flows in learning configurations has become of principal strategic importance for organisations. Value is now created through innovation. Innovation is needed to create competitive advantage. Bolton and Lane (2012) find that individual or firm entrepreneurial orientation is important to organisational success. Innovativeness, risk-taking, and proactiveness are vital to organisational survival and success. Bagheri and Pihie (2011) point out that there are two specific types of competencies for the leaders of entrepreneurial venturing. These are personal competencies and functional competencies. Personal competencies include proactiveness, innovativeness, and risk taking.

Under conceptual competencies, planning, organising and decision making are of high importance. In addition, under personal competencies and traits, honesty and integrity has the highest mean of 5.00. Thach \& Thompson (2007) point out that competencies for effective leadership include vision and goal-setting, planning, organising, interpersonal skills, self-knowledge and technical competence. Other competencies include integrity/honesty, communication, diversity consciousness, problem-solving, decision team leadership, conflict management and social and environmental 
responsibility,

\subsection{Challenges}

The results indicate that one of the challenges in leading a student entrepreneurship organisation is poor commitment from members. Members at times do not attend meetings or participate in projects. Many members join the organisation for wrong reasons such as believing that they will only go on trips to national competitions. Another challenge is getting sponsors for projects. This delays progress in the project. Weak communication between the executive management and the members of the organisation is another identified challenge. The results are consistent the findings of Bagheri and Pihie (2011) that lack of interest and commitment in entrepreneurial activities among the group members is one of the challenges that student entrepreneurial leaders face in leading university entrepreneurship programs.

\section{Conclusions}

The study investigated the competencies that are needed to successfully lead a student entrepreneurship organisation. In addition, the study sought to identify the challenges that student entrepreneurship organisations leaders face in achieving goals. The results indicated that communication, team work, time management and honesty and integrity are the most important competencies and traits that are needed to successfully lead a student entrepreneurship organisation. The results also indicated that a major challenge to achieving goals is the lack of commitment by members. The study has some limitations. The survey was conducted in only one university and on only one student entrepreneurship organisation. Therefore, care should be exercised in the generalisation of the results. Other studies can expand the study to more universities and more student entrepreneurship organisations. A bigger population will allow similar studies to investigate the impact of personal attributes such as gender on the competencies of the leaders of entrepreneurship organisations.

\section{References}

Arham, A.F., Boucher, C., \& Muenjohn, N. (2013). Leadership and Entrepreneurial Success: A Study of SMEs in Malaysia. World Journal of Social Sciences, 3(5):117-130.

Baker, D.P., Day, R., \& Salas, E. (2006). Teamwork as an Essential Component of High-Reliability Organizations. Health Services Research, 41(4): 1576-1598.

Bagheri A., \& Pihie, Z.A.L. (2011). Student Entrepreneurial Leaders: Challenges and Competencies of Leading University Entrepreneurship Programs. International Journal of Business and Social Science, 2 (2):133-144.

Baum, J.R., Locke, E.A.,\& Smith, K.G. (2001), A multidimensional model of venture growth. Academy of Management Journal, 44(2): 292-303.

Becker, G. (1994). Human Capital: A Theoretical and Empirical Analysis with Special Reference to Education (3rd ed.). Chicago. The University of Chicago Press.

Beeka, B.H., \& Rimmington, M. (2011).Entrepreneurship as a career option for African youths. Journal of Development Entrepreneurship, 16(1): 145-164.

Bolton, D.L., \& Lane, M.D., (2012). Individual entrepreneurial orientation: development of a measurement instrument. Education + Training, 54( 2/3):.219-233.

Buang, N.A. (2011). Managing Quality Entrepreneurship Course for Community College Students in Malaysia. International Business Management, 5(5): 255-265.

DiMattia, Ernie, (2013). Leadership and Management in Action [Online] Available: http://lj.libraryjournal.com/2013/03/opinion/focus-onleadership- (February 7, 2014)

Dixon, R., Meier, R. L., Brown, D. C., \& Custer, R. L. (2005). The critical entrepreneurial competencies required by instructors from institution-based enterprises: A Jamaican study. Journal of Industrial Teacher Education, 42(4): 25-51.

Enactus (2014). Who are we. [Online] Available: http://enactus.org/who-we-are/our-story/_(March 9, 2014)

Gruban, B. (2003). Kompetence: Moda, Ki Traja Že Štiri Desetletja. Finance, 168/1596, str. 19

Gupta, V., MacMillan, I.C., \& Surie, G. (2004). Entrepreneurial Leadership: Developing and Measuring a Cross-Cultural Construct. Journal of Business Venturing, 19: 241-260.

Hellriegel, D., Jackson, S.E., Slocum, J., Staude, G., Amos, T., Klopper, H.P., Louw, L. \& Oosthuizen, T. (2008). Management. Second South Africa edition. Oxford: Oxford University Press.

Inyang B.J., \& Enuoh, R.O (2009). Entrepreneurial Competencies: The Missing Links to Successful Entrepreneurship in Nigeria. International Business Research, 2(2): 62-71.

Kettunen, J. (2011) Innovation Pedagogy for Universities of Applied Sciences. Creative Education, 2(1): 56-62.

Kiggundy, M. (2002). Entrepreneurs and entrepreneurship in Africa: What is known and what needs to be done. Journal of 
Developmental Entrepreneurship, 7(3): 239 - 258

Lourenço, F., Taylor, T.G., Taylor, D.W. (2013).Integrating education for entrepreneurship in multiple faculties in "half-the-time" to enhance graduate entrepreneurship. Journal of Small Business \& Enterprise Development, 20(3): 503 - 525.

Man, T.W.Y., Lau, T., Chan, K.F. (2002). The competitiveness of small and medium enterprises: a conceptualisation with focus on entrepreneurial competencies. Journal of Business Venturing, 17(2)::123-142

Moghimi, S.F., Chamanzamin, M.R. \& Shaghaghi, A. M. (2013). The Relationship between Communication Skills and Job Performance of the Employees, Fire Managers of Rasht City. International Journal of Business and Behavioural Sciences, 3(2): 60-75.

Pagon, Milan, Banutai, Emanuel, Bizjak, Uroš. (2008). Leadership competencies for successful change management. [Online] Available: http://www.funzionepubblica.gov.it/ (March 2, 2014).

Mitchelmore, S., \& Rowley, J. (2013) Entrepreneurial competencies of women entrepreneurs pursuing business growth. Journal of Small Business and Enterprise Development, 20(1): 125 - 142

Olupeliyawa, A.M., Hughes, C., \& Balasooriya, C.D (2009). A review of the literature on teamwork competencies in healthcare practice and training: Implications for undergraduate medical education. South East Asian Journal of Medical Education, 3(2):61-72.

Onstenk, J. (2003). Entrepreneurship and vocational education. European Education Research Journal, 2(1): 74-89.

Payne, H.J. (2005). Reconceptualizing Social Skills in Organizations: Exploring the Relationship between Communication Competence, Job Performance, and Supervisory Roles. Journal of Leadership \& Organizational Studies, 11(2): 63-77.

Phelan, C., \& Sharpley, R. (2012). Exploring entrepreneurial skills and competencies in farm tourism. Local Economy 27(2): 103-118.

Penchev, P., Salopaju, A. (2011). Entrepreneurial Competencies Needed by Managers in their Work. Unpublished Masters Thesis, Jonkoping: Jonkoping University.

Prewitt, J., Weil, R., \& McClure, A. (2011). Developing leadership in global and multi-cultural organizations. International Journal of Business \& Social Science, 2(13): 13-20.

Sardeshmukh, S.R., \& Smith-Nelson, R. (2011). Educating for an entrepreneurial career: developing opportunity recognition ability. Australian Journal of Career Development, 20(3): 47-55.

Schultz, T.W (1961). Investment in human capital. The American Economic Review, 1(2): 1-17.

Slavkin, H.C. (2010). Leadership for health care in the 21st Century: A personal perspective. Journal of Healthcare Leadership, 2, 35-41

Stoof, A. (2005).Tools for Identification and Description of Competencies. Unpublished Thesis Dissertation, Heerlen: Open University of Netherlands.

Svetlik, I. (2005) on competence. (2nd ed.) Ljubljana: GV Education

Tarabishy, A., Solomon,G., Fernald, L.W., \& Sashkin, M. (2005). The entrepreneurial leader's impact on the organization's performance in dynamic markets. Journal of Private Equity 8 (4): 20-29.

Thach, E., Thompson, K. J. (2007). Trading places - Examining leadership competencies between for-profit vs. Public and non-profit leaders. Leadership \& Organization Development Journal, 28 (4)356-375.

Vathanophas, V., Thai-ngam, J. (2007). Competency Requirements for Effective Job Performance in The Thai Public Sector, Contemporary Management Research, 3(1): 45-70.

Winston, B. E., \& Patterson, K. (2006). An Integrative Definition of Leadership. International Journal of Leadership Studies, 1(2): 6-66

Yang, C.W. (2008). The Relationships Among Leadership Styles, Entrepreneurial Orientation, and Business Performance. Managing Global Transitions, 6 (3): 257-275.

Zeng, F., Bu, X., \& Su,L. (2011). Study on entrepreneurial process model for SIFE student team based on Timmons model. Journal of Chinese Entrepreneurship, 3(3): 204 - 214. 